\title{
Socially Excluded Communities and the Inclusive Labour Market in the Slovak Republic
}

\author{
Richard PRIESOL*
}

\begin{abstract}
In this paper, we construct a computable general equilibrium model of the Slovak economy to evaluate an impact of different types of inclusive programmes on an economic performance. Furthermore, we apply individual microeconomic data to identify socially excluded communities and place them in the inclusive labour market in a form of inclusive employers or social enterprises. While the first ones operate as standard producers with additional subventions from government, the latter ones are explicitly designed for the employment of socially excluded communities. Our results show that both types of inclusive programmes help to reduce structural unemployment and improve potential production in the Slovak economy. While the application of the inclusive employers leads to a better improvement of potential production, in line with a higher productivity of production factors, the application of the social enterprises leads to a more significant reduction in structural unemployment, due to an absence of social dumping on the domestic labour market.
\end{abstract}

Keywords: social exclusion, structural unemployment, inclusive labour market, social dumping, general equilibrium theory

JEL Classification: C68, J21, J71

DOI: https://doi.org/10.31577/ekoncas.2021.10.04

\section{Introduction}

Social exclusion of minorities presents one of the most serious problems for the Slovak Republic from both social and economic point of view. Structural differences in living standards and social relations with a respect to the major population lead to a formation of generational poverty and direct and latent

\footnotetext{
* Richard PRIESOL, Institute for Financial Policy, Ministry of Finance of the Slovak Republic, Štefanovičova 5, 817 82, Bratislava, Slovakia and Faculty of Mathematics, Physics and Informatics, Comenius University in Bratislava, Mlynská dolina, 842 48, Bratislava, Slovakia; e-mail: richard.priesol@gmail.com
} 
discrimination of the excluded communities. Furthermore, an absence of necessary education and working habits results in a formation of structural unemployment with a negative impact on potential production. Finally, the unfortunate combination of these factors makes it extremely difficult to break the loop of social exclusion and thus improve the current situation of the excluded communities.

As suggested by a number of studies, the inclusive employment proposes one of the most promising methods to limit social exclusion and reduce structural unemployment, since a positive experience with the labour market could have a significant impact on social interactions and working habits of socially excluded communities and thus improve their labour market prospects (Páleník et al., 2013). Furthermore, an additional income could help to improve living standards and reduce generational poverty of socially excluded communities, while their integration to the labour market could help to reduce direct and latent discrimination from the major population.

In this paper, we focus on two different forms of inclusive employment, i.e. inclusive employers and social enterprises. While the inclusive employers operate as standard producers aiming to maximize their profits that obtain subventions from government for employing socially excluded communities, the social enterprises are explicitly designed for inclusive employment and operate similarly to non-profiting institutions. To compare these different forms of inclusive employment, we construct a computable general equilibrium model with a three-level production function that incorporates both standard and inclusive employees under different aggregation forms.

Specifically, we incorporate standard and inclusive employees into a production function as either perfect substitutes for the inclusive employers or perfect complements for the social enterprises. Since the inclusive employers aim to maximize their profits, they substitute both population groups in line with their productivity and labour costs. It is important to note that the labour costs of inclusive employees are partially compensated by subsidies from government. Therefore, they could be relatively effective for domestic producers despite their lower productivity. On the other hand, the social enterprises aim to provide the most inclusive environment for socially excluded communities and thus need to incorporate a fixed number of inclusive managers for a fixed number of inclusive employees. The labour costs of inclusive employees are then fully compensated by subsidies from government.

Furthermore, we need to distinguish between (i) standard and inclusive producers to incorporate the structure of the domestic labour market with two types of employees and (ii) standard and excluded households to incorporate the income 
from the inclusive programmes and its impact on a behaviour of households. ${ }^{1}$ This approach thus allows us to model different types of inclusive programmes and evaluate their dynamic effects on domestic producers and households.

We need to mention that the decomposition of producers and households is based on individual microeconomic data, due to an absence of macroeconomic alternatives and a lack of related literature. Therefore, to avoid arbitrary assumptions about the structure of excluded communities and inclusive producers, we tend to apply microeconomic data to identify different types of producers and households. Furthermore, we need to apply microeconomic data to calibrate a mobility function of inclusive employees.

Computable general equilibrium models are regularly applied for evaluations of different tax policies, environmental regulations and trade strategies, due to their simple but rich structure, consistency with a macroeconomic theory and the ability to capture sectoral linkages within world economies. ${ }^{2}$ Furthermore, these models could be applied also for an evaluation of potential benefits from the inclusive employment (Kabir and Dudu, 2020). It is important to note that there is a number of advantages of this approach over partial equilibrium methods, since we are able to capture (i) structural relationships in the Slovak economy, (ii) a different productivity of standard and inclusive employees, (iii) a different structure of standard and inclusive producers, (iv) different consumption habits of standard and excluded households and (v) dynamic effects of the inclusive programmes.

The paper is structured as follows. First, we provide a literature review of the most recent studies about consequences of social exclusion and different types of inclusive programmes. Second, we propose a computable general equilibrium model of a small open economy with two types of producers and two types of households. Third, we present an underlying dataset and describe the construction of a social accounting matrix. Finally, we evaluate an impact of different types of inclusive programmes on the Slovak economy and their implications in terms of structural unemployment and potential production.

\section{Related Literature}

There is a number of social and economic issues that result from social exclusion of minorities. One of the most negative consequences is without a doubt a formation of generational poverty. The theory of poverty traps stands in contrast to a popular assumption that a lack of disposable income could be overcome by

\footnotetext{
${ }^{1}$ While the standard producers do not participate in the inclusive programmes, the inclusive producers operate as either inclusive employers or social enterprises.

${ }^{2}$ For an introduction to computable general equilibrium models and their possible applications see Dixon and Jorgenson (2012) or Burfisher (2017).
} 
hard work and a reduction in consumption. Contrary to this, an economic system requires a lot of physical and human capital to escape the poverty trap what leads to a self-reinforcing cycle of poverty. The acquisition of capital could be further limited by market or institutional failures what limits an individual responsibility for poverty (Azariadis and Stachurski, 2004). However, the detection of the poverty traps could be problematic due to short data samples and measurement errors (Antman and McKenzie, 2007).

It is then important to define alternative measures for economic growth that incorporate a degree of poverty reduction and inequality improvement over time, for example the poverty bias of growth (McCulloch and Baulch, 2000), the propoor growth index (Kakwani and Pernia, 2000) or the poverty equivalent growth rate (Kakwani and Son, 2008). On the other hand, we should be interested not only in the reduction of poverty but in both pace and pattern of economic growth with a focus on sustainability and inclusiveness, or in other words, in the inclusive growth. The constraints to the inclusive growth are then determined by an access to domestic and international markets, a distribution of information and education and an effectiveness of government (Ianchovichina and Lundstrom, 2009).

Therefore, we need to question, whether the economic growth in the Slovak Republic was able to reduce income inequalities between the excluded communities and the major population and thus limit the formation of generational poverty. However, since we observe a negative relationship between an increase in economic growth and a decline in income inequalities (Domonkos et al., 2013), we could assume that the economic growth in the Slovak Republic was not oriented on the excluded communities. An important objective should be then the evaluation of different types of labour market policies and their impact on an economic performance and a degree of social exclusion (Páleník et al., 2015).

Another important consequence of social exclusion is a formation of structural unemployment with further negative implications for potential production. This is a very relevant issue for the Slovak economy that is negatively affected by excessive levels of structural unemployment with a regional concentration and an accumulation of social exclusion (Páleník, 2015). Even though the Slovak Republic is in the middle of the European countries in terms of national unemployment on the level of $6.7 \%$, it has one of the highest rates of long-term unemployment in the European Union on the level of 3.2\%. ${ }^{3}$ The reduction of structural unemployment could be then achieved by boosting a labour demand with new work positions and wage subsidies for employers, or by supporting human capital with education and training of excluded communities (Jusko, 2015).

\footnotetext{
${ }^{3}$ These numbers are consistent with the Labour Force Survey of the European Union (2020) and are obtained from the Eurostat database.
} 
We continue with a comparison of different types of inclusive programmes, with a focus on public employment, wage subsidies, job search assistance and training programmes. While the direct employment in a public sector frequently appears detrimental, the wage subsidies in a private sector can be effective in improving labour market outcomes (Kluve, 2010). Furthermore, both of these policies could have a negative impact in a short horizon but then gradually improve and turn positive in a long horizon (Vooren et al., 2018). Finally, the job search assistance is more effective in a short horizon and the training programmes are more effective in a long horizon (Card et al., 2010).

Even though the inclusive programmes could be less effective then policymakers usually assume (McKenzie, 2017), they could reduce unemployment rates and increase participation rates and seem to be particularly beneficial for low-skilled participants (Escudero, 2018). We need to mention that we focus on the demand types of inclusive programmes, i.e. public employment and wage subsidies. An evaluation of the supply types of inclusive programmes is beyond the scope of this paper.

\section{Macroeconomic Model}

To compare different types of inclusive programmes and evaluate their potential impact on an economic performance, we construct a recursive dynamic computable general equilibrium model of a small open economy with two types of producers and two types of households. We further define a three-level production function that incorporates both standard and inclusive employees under different aggregation forms for inclusive employers and social enterprises. The number of inclusive employees is set by the government under a transformation function for employment subventions. On the other hand, the number of standard employees is implied by an optimal allocation of production factors. Finally, we provide a dynamization of the model with an accumulation function of a capital stock and a mobility function of inclusive employees that is extended for a negative impact of social dumping.

\subsection{Domestic Employment}

We apply a three-level production function for the inclusive producers to differentiate between alternative forms of inclusive employment. In the first step, we aggregate both types of employees (LE) into a labour production factor (LT) of inclusive producers under different aggregation forms for inclusive employers and social enterprises. We label the standard employees by $s$, the inclusive employees by $i$ and time periods by $t$. 
In the case of inclusive employers, we assume that these producers aim to maximize their profits from both labour inputs based on their productivity and labour costs. We thus assume that a fixed number of standard employees could be substituted for a fixed number of inclusive employees and aggregate them as perfect substitutes under a linear functional form (Eq. 1). While the labour costs of standard employees are paid only by the producers and are thus subject to the optimization process, the labour costs of inclusive employees are partially paid by the subsidies from government and only a part of them is set by the optimal allocation of production factors.

$$
L T_{i, t}=\kappa_{s} * L E_{s, t}+\kappa_{i} * L E_{i, t}
$$

In the case of social enterprises, we assume that these producers aim to provide the most inclusive environment for socially excluded communities and thus need to incorporate a fixed number of inclusive managers for a fixed number of inclusive employees. Both types of employees are then perfectly complemental to each other and we aggregate them under a Leontief functional form (Eq. 2). Specifically, we assume that one inclusive manager is necessary for the employment of four inclusive employees in a baseline scenario and then provide a sensitivity analysis for this parametrization.

$$
L T_{i, t}=1 / \pi_{s} * L E_{s, t}=1 / \pi_{i} * L E_{i, t}
$$

To close the model, we need to impose two additional restrictions on the distribution of standard and inclusive employees on the domestic labour market. First, we assume that the government controls for the number of inclusive employees that are set exogenous to the model (IN) and thus need to write $L E_{i, t}=I N_{t}$. Second, we assume a perfect mobility of labour of standard employees (Corong et al., 2017) and thus need to write $P E_{s, t}=P L_{s, t}$ for the labour costs of employees (PE) and the price of labour (PL). The labour production factor (LT) of standard producers is then equal to a simple difference between domestic employment (DE) and the number of standard employees or inclusive managers that are implied by the inclusive producers (Eq. 3). ${ }^{4}$

$$
L T_{s, t}=D E_{t}-L E_{s, t}
$$

The inclusive managers operate as standard employees under average labour costs that are set by the optimal allocation of production factors. On the other hand, the labour costs of inclusive employees are paid by the government and are

\footnotetext{
${ }^{4}$ We need to mention that the domestic employment in the model consists only of the standard employees and not the inclusive employees.
} 
thus not subject to the optimization process. Social enterprises are thus more expensive than inclusive employers for the government, since no part of the labour costs of inclusive employees is paid by the producers. Furthermore, since the government controls for the number of inclusive employees, it controls also for the number of inclusive managers in social enterprises, what leads to the crowding out of the labour factor from more effective production sectors and thus limits the formation of value added in the domestic economy.

\subsection{Domestic Production}

In the second step, we incorporate a labour factor (LT) and a capital factor (KT) to explain value added (VA) in both production sectors under a CobbDouglas functional form (Eq. 4). We thus assume a unit elasticity of substitution between labour and capital production factors, in line with the empirical literature (Lichner and Miklošovič, 2011). Even though on the level of individual industries, the estimates of substitution elasticities are significantly different from unity, the average substitution elasticity in the Slovak economy is estimated close to unity and thus does not reject the Cobb-Douglas function. We further label the production sectors by $c$ and time periods by $t$.

$$
V A_{c, t}=\psi_{c} * L T_{c, t}^{\varphi_{c}} * K T_{c, t}^{1-\varphi_{c}}
$$

On the other hand, we aggregate intermediate inputs of standard and inclusive commodities under a Leontief functional form (Eq. 5) to obtain intermediate consumption (IC) in both production sectors. The Leontief function is regularly applied for the aggregation of sectoral commodities under an assumption that different production sectors, for example agriculture and construction, produce complemental products that could not be replaced by each other in a production chain. This functional form would be thus accurate if the standard producers and the inclusive producers operate in different production sectors. We could then see from microeconomic data that the inclusive producers are significantly biased towards the sector of manufacturing, and are thus relatively complemental to the standard producers. We label the production sectors by $c$, the standard commodities by $s$, the inclusive commodities by $i$ and time periods by $t$.

$$
I C_{c, t}=1 / \omega_{s} * I C_{c, s, t}=1 / \omega_{i} * I C_{c, i, t}
$$

In the last step, we model total production (YT) in both production sectors as a function of value added (VA) and intermediate consumption (IC). We assume that the degree of substitution between these production factors could be different from unity and thus merge them under a Constant elasticity of substitution 
function (Eq. 6). Furthermore, we link the parameter of substitution $\theta_{p}$ to the elasticity of substitution $\sigma_{p}$ with a transformation function $\theta_{p}=1-1 / \sigma_{p}{ }^{5}$ The corresponding prices are pinned down by the first order conditions, in line with a zero-profit assumption. ${ }^{6}$

$$
Y T_{c, t}^{\theta_{p}}=\alpha_{c}^{\theta_{p}} * \beta_{c} * V A_{c, t}^{\theta_{p}}+\alpha_{c}^{\theta_{p}} *\left(1-\beta_{c}\right) * I C_{c, t}^{\theta_{p}}
$$

Estimation of the elasticity of substitution $\sigma_{p}$ is based on the first order conditions, in contrast to the direct estimation of the production function. While the direct approach requires an application of differential equations and constant growth rates to incorporate the Hicks neutral component $\alpha_{\mathrm{c}}$ that increases over time, the estimation based on the first order conditions abstract from this parameter, in line with the first derivation of the production function, and thus provides much simpler and less biased estimation. Furthermore, since we calibrate the Hicks neutral component $\alpha_{\mathrm{c}}$ from a benchmark period, we prefer not to estimate it from historical data.

\subsection{Domestic Households}

Consumption of commodities by standard and excluded households is based on a theory of utility maximization. Specifically, we assume that both types of households maximize their utility from standard and inclusive commodities under a Stone-Geary functional form (Eq. 7) that is suitable for different types of households with different living standards and poverty levels. The Stone-Geary function distinguishes between necessary and additional consumption where the first one captures a subsistence minimum of particular households and the latter one captures a marginal utility from additional consumption of particular commodities. It further implies that the total consumption (CT) of the commodity $c$ by the household $h$ consists of the necessary consumption (NC) of the commodity c by the household $h$ and a share of the commodity $c$ on the additional consumption of the household $h$. The additional consumption of the household $h$ is then equal to a disposable income (DI) of the household $h$ minus the necessary consumption of both types of commodities. Finally, we adjust the equation for prices of particular commodities (PQ).

$$
C T_{h, c, t}=N C_{h, c, t}+\gamma_{c} * \frac{D I_{h, t}-\sum_{c} N C_{h, c, t} * P Q_{c, t}}{P Q_{c, t}}
$$

\footnotetext{
${ }^{5}$ We modify the standard definition of the CES function with a negative exponent.

${ }^{6}$ It is important to note that the zero profit of domestic producers does not imply the zero profit of domestic firms, since we incorporate a net operating surplus into the price of capital.
} 
Next, we determine a disposable income of both types of households from budgetary restrictions and constant savings rates. It is important to note that the savings of excluded households are set to zero under an assumption that the excluded communities consume the entire earnings. However, we need to mention that even though the standard households save a part of their earnings, they still consume more per person than the excluded households. Calibration of the subsistence minimum is then based on the Frisch parameter of substitution that is set to 1.05 , in line with the related literature. ${ }^{7}$ Even though the Frisch parameter does not directly enter the Stone-Geary function, the calibration of the subsistence minimum is essentially based on a value of this parameter (Gharibnavaz and Verikios, 2018). We further assume that the subsistence minimum per person is equal across different types of households and varies only for different types of commodities and thus calibrate the necessary consumption of standard and excluded households from the subsistence minimum per person and the number of persons within both population groups.

\subsection{International Trade}

Export and import of both types of commodities is captured by the Armington model of international trade. We thus assume that the total production (YT) of standard and inclusive commodities distributes between both domestic sales (DT) and domestic export (XT) under a Constant elasticity of transformation function (Eq. 8). Furthermore, we link the parameter of transformation $\theta_{x}$ to the elasticity of transformation $\sigma_{x}$ with a transformation function $\theta_{x}=1+1 / \sigma_{x}$. The export prices are set exogenous to the model what comes as natural in a small open economy without an independent monetary policy.

$$
Y T_{c, t}^{\theta_{x}}=v_{c}^{\theta_{x}} * \xi_{c} * X T_{c, t}^{\theta_{x}}+v_{c}^{\theta_{x}} *\left(1-\xi_{c}\right) * D T_{c, t}^{\theta_{x}}
$$

On the other hand, we assume that the total consumption (QT) of standard and inclusive commodities consists of both domestic sales (DT) and domestic import (MT) under a Constant elasticity of substitution function (Eq. 9). It is important to note that the import of inclusive commodities is set to zero, since the total amount of inclusive commodities is equal to the production of inclusive producers. Furthermore, we link the parameter of substitution $\theta_{m}$ to the elasticity of substitution $\sigma_{m}$ with a transformation function $\theta_{m}=1-1 / \sigma_{m}$. Again, the import prices are set exogenous to the model.

$$
Q T_{c, t}^{\theta_{m}}=v_{c}^{\theta_{m}} * \zeta_{c} * M T_{c, t}^{\theta_{m}}+v_{c}^{\theta_{m}} *\left(1-\zeta_{c}\right) * D T_{c, t}^{\theta_{m}}
$$

\footnotetext{
${ }^{7}$ For further references see Miklošovič (2014).
} 
Estimation of the trade elasticities is based on the first order conditions, in line with the empirical literature. Specifically, we perform a logarithmic transformation of the first order conditions and estimate them from historical time series of real and price variables (Gallaway et al., 2003). The estimates of both trade elasticities are significantly higher than unity and thus impose a high degree of substitution and transformation between domestic and external markets. The estimation results are thus in line with the related literature. ${ }^{8}$

\subsection{Clearing of Markets}

Model closure is based on a constant depreciation rate for both production sectors and a constant savings rate for both types of households. We thus assume that the agents in the economy maintain their preferences over time. Furthermore, we need to exogenize public consumption (GT) to estimate dynamic effects of different types of inclusive programmes on a public sector deficit and a public sector debt. Finally, we exogenize inventories and valuables (VT) and thus obtain a total amount of investment (IT) from the savings to investment identity, in line with the Walras's law. Distribution of the domestic investment between standard and inclusive commodities is then based on a Leontief functional form (Eq. 10) and is thus fixed in constant proportions. We label the standard commodities by $s$, the inclusive commodities by $i$ and time periods by $t$.

$$
I T_{t}=1 / \mu_{s} * I T_{s, t}=1 / \mu_{i} * I T_{i, t}
$$

Next, we exogenize the number of standard and inclusive employees in each simulation period and thus close the labour market. Distribution of the standard employees between both production sectors is then implied by a perfect mobility of labour. On the other hand, the amount of the inclusive employees on the domestic labour market is set by the government. Furthermore, we exogenize a capital stock in both production sectors in each simulation period and thus close the capital market. Finally, we choose the consumer price index as the model numeraire and close the commodity market by a market clearing condition for standard and inclusive commodities (Eq. 11). ${ }^{9}$ Again, we label the sectoral commodities by $c$, the standard producers by $s$, the inclusive producers by $i$, the standard households by $s$, the excluded households by $e$ and time periods by $t$.

$$
Q T_{c, t}=I C_{s, c, t}+I C_{i, c, t}+C T_{s, c, t}+C T_{e, c, t}+G T_{c, t}+I T_{c, t}+V T_{c, t}
$$

\footnotetext{
${ }^{8}$ For an overview of the estimation results see Hillberry and Hummels (2012).

${ }^{9}$ Common price indices are regularly chosen as model numeraires to avoid issues with microeconomic closures, for further explanation see Ezaki (2006).
} 


\subsection{Subvention Function}

We assume that the government controls for the number of inclusive employees in each simulation period by subventions to inclusive producers. Therefore, we could calibrate the subventions per person from a benchmark period, fix them as constant on a simulation horizon and thus determine the number of inclusive employees in each simulation period. On the other hand, we could argue that an inelastic relationship between the number of participants and the subventions per person is questionable, since an incentive of both producers and households to participate in the inclusive programmes could decline with a degree of social exclusion and thus with the number of participants..$^{10}$ In line with this assumption, we need to incorporate a negative relationship between the number of participants in each simulation period and their incentive to participate in the inclusive programmes. The labour income per person $(\Lambda)$ should be then defined as an increasing function of the number of inclusive employees (IN) to motivate more excluded persons to participate in the inclusive programmes (Eq. 12).

$$
\Lambda_{t}=\eta_{1}+\eta_{2} * I N_{t}
$$

We choose a linear functional form for convenience and a lack of additional information but the application of other increasing functional forms is also possible. Calibration of the parameters is then based on the number of inclusive employees in a benchmark period and an additional assumption about a minimal labour income implied by the subventions per person. Specifically, we set the number of inclusive employees to zero if the labour income of employees is less than an official minimum wage.

\subsection{Labour Dynamization}

Dynamization of the model is implied by additional equations for labour and capital production factors. Specifically, we exogenize these variables in each simulation period by corresponding dynamic equations and thus provide a microeconomic closure to the model. First, we determine the domestic employment (DE) by a mobility function of inclusive employees (Eq. 13). We thus assume that an actual value of the domestic employment is equal to a previous value of the domestic employment and a share of inclusive employees (IN) from a previous simulation period that are able to find a work position in an actual simulation period. On the other hand, we assume that once the inclusive employees find a work

\footnotetext{
${ }^{10} \mathrm{We}$ assume that the number of participants in the inclusive programmes is proportional to a degree of social exclusion of the last participant. In other words, the least excluded persons are the first ones to participate in the inclusive programmes and the opposite holds for the most excluded persons.
} 
position, they become the standard employees and do not return to the inclusive programmes. We thus do not define a mobility function of standard employees, only a mobility function of inclusive employees.

$$
D E_{t+1}=D E_{t}+\Gamma_{t} * I N_{t}
$$

In a baseline scenario, we calibrate the mobility of inclusive employees from historical data and fix it as constant on a simulation horizon. ${ }^{11}$ However, we could argue that since the number of participants in the inclusive programmes depends on the subventions per person and could thus vary over time, we need to incorporate an additional relationship between the subventions per person and the mobility of inclusive employees. For example, it could be more profitable for inclusive employers to participate in the inclusive programmes with additional subventions from government than offer a regular job to inclusive employees. This could be viewed as a form of social dumping that should be positively correlated with the subventions per person. An increase in the subventions per person should thus lead to a decline in the mobility of inclusive employees, due to an increase of the social dumping. We then incorporate a negative relationship between the mobility of inclusive employees $(\Gamma)$ and the subventions per person (П) in each simulation period (Eq. 14).

$$
\Gamma_{t}=\lambda_{1}-\lambda_{2} * \Pi_{t}
$$

Again, we choose a linear functional form for convenience and a lack of additional information but the application of other decreasing functional forms is also possible. Calibration of the parameters is then based on the subventions per person in a benchmark period and an additional assumption about a maximal labour income implied by the subventions per person. Specifically, we set the mobility of inclusive employees to zero if the labour income of employees is more than an official mean wage. Next, the subventions per person (П) are equal to a simple difference between the labour income per person $(\Lambda)$ and the labour costs per person (PE) in each simulation period (Eq. 15).

$$
\Pi_{t}=\Lambda_{t}-P E_{i, t}
$$

On the other hand, since the social enterprises do not aim to maximize their profits from production, we assume that the mobility of inclusive employees is independent from the subventions per person and thus constant in each simulation period. The social enterprises should thus have a more positive impact on the domestic employment than the inclusive employers.

\footnotetext{
${ }^{11}$ The historical mobility of inclusive employees is obtained from the individual microeconomic data of the Institute for Financial Policy (IFP).
} 


\subsection{Capital Dynamization}

Next, we determine the capital stock in the standard sector (SK) by an accumulation function of standard capital (Eq. 16). An actual value of the capital stock is thus equal to a previous value of the capital stock that is adjusted for a capital depreciation rate $(\delta)$ and a share of domestic investment (IT) from a previous simulation period. The share of investment $(\Omega)$ is equal to a ratio between the allocation of investment in the standard sector and a sum of investment allocations in both production sectors. The allocation of investment between standard and inclusive sectors is further based on a return of capital (Jung and Thorbecke, 2001). To unify the model notation, we need to write $K T_{s, t}=S K_{t}$ for the capital factor of standard producers.

$$
S K_{t+1}=\left(1-\delta_{s}\right) * S K_{t}+\Omega_{s, t} * I T_{t}
$$

Finally, we determine the capital stock in the inclusive sector (IK) by an accumulation function of inclusive capital (Eq. 17). The share of investment $(\Omega)$ is equal to a ratio between the allocation of investment in the inclusive sector and a sum of investment allocations in both production sectors. To unify the model notation, we need to write $K T_{i, t}=I K_{t}$ for the capital factor of inclusive producers.

$$
I K_{t+1}=\left(1-\delta_{i}\right) * I K_{t}+\Omega_{i, t} * I T_{t}
$$

\section{Data and Calibration}

Calibration of model parameters is based on a social accounting matrix (SAM) that incorporates structural relationships between macroeconomic variables in a benchmark period (2016). Specifically, the matrix captures nominal flows in the economy to describe production and consumption of goods and services and intersectoral transfers between sectors of households, firms, government and external world.

Calibration of the matrix is then based on national and sectoral accounts of the Statistical Office of the Slovak Republic (Table 1). The national accounts provide information about production and consumption of goods and services. On the other hand, the sectoral accounts describe nominal flows between households, firms, government and external world. We further construct a matrix of intersectoral transfers to capture the distribution of primary and secondary incomes. Calibration of the fiscal variables is then based on government finance statistics of the Eurostat (Table 1). 
Finally, we disaggregate the matrix for standard and inclusive producers and standard and excluded households.

Table 1

Aggregate Macroeconomic Variables in a Benchmark Period (2016)

\begin{tabular}{|l|r|l|r|}
\hline Gross domestic product & 81226.073 & Private consumption & 44372.371 \\
Public consumption & 15739.218 & Domestic investment & 17279.938 \\
Domestic inventories & 1386.353 & Total trade balance & 2448.193 \\
Domestic production & 192583.981 & Intermediate inputs & 1197.786 \\
Gross value added & 73436.195 & Total labour factor & 36986.501 \\
Total capital factor & 36386.714 & Taxes on production & 62.980 \\
Domestic employment & 2321.049 & Migration balance & 171.069 \\
Total unemployment & 265.996 & Total inactive persons & 1836.095 \\
Public sector deficit & 2320.207 & Public sector debt & 42053.200 \\
\hline
\end{tabular}

Note: * Domestic employment, migration balance, total unemployment and total inactive persons are provided in thousands of persons. Other macroeconomic variables are provided in millions of euro.

Source: Statistical Office of the Slovak Republic, Eurostat of the European Commission.

Decomposition of the national population into standard and excluded households is implied by a database of excluded communities that is obtained from the Institute for Financial Policy (IFP). The database is based on individual microeconomic data and a set of social and economic characteristics (Hidas et al., 2018). Next, we extract the inclusive programmes from a database of active labour market policies with a focus on the wage subsidies on private and regional employment, to capture subventions for employers in exchange of offering work positions to the excluded communities. ${ }^{12}$

We then merge the database of active labour market policies with the database of excluded communities to identify the number of inclusive employees and the subventions on inclusive programmes in a benchmark period (Table 2). Next, we merge the database of excluded communities with the database of labour market participants and identify a share of inclusive employees that are able to find a work position in a next simulation period. Finally, we merge the database of excluded communities with the database of social benefits and thus identify the disposable income of both types of households (Table 2).

Decomposition of total production between standard and inclusive producers is based on a database of domestic firms from the Institute for Financial Policy (IFP). Specifically, we merge the database of domestic firms with the database of active labour market policies and thus identify the producers that participate in the inclusive programmes. We can then determine the production chain of value

\footnotetext{
12 We include active labour market policies with a respect to following paragraphs: P047, P050, P50J, P50K, P51A, P054, P54R, P54U. For further information see for example <https://www.upsvr.gov.sk/sluzby-zamestnanosti/nastroje-aktivnych-opatreni-na-trhuprace.html?page_id=13313>.
} 
added and intermediate inputs of both types of producers (Table 2). Furthermore, we extract the labour costs of standard and inclusive employees and thus approximate the labour productivity of both types of employees (Table 2). Finally, we are able to identify a share of labour costs paid by the producers and a share of labour costs paid by the government on the domestic labour market.

Table 2

\section{Sectoral Macroeconomic Variables in a Benchmark Period (2016)}

\begin{tabular}{|l|r|l|r|}
\hline Standard population & 4528.133 & Excluded population & 66.076 \\
Standard employees & 2317.297 & Inclusive employees & 3.752 \\
Total standard income & 45615.289 & Total excluded income & 109.337 \\
Standard subventions & 0.000 & Inclusive subventions & 10.135 \\
Standard production & 189138.540 & Inclusive production & 445.441 \\
Standard labour costs & 36960.784 & Inclusive labour costs & 25.717 \\
\hline
\end{tabular}

Note: * Standard population, excluded population, standard employees and inclusive employees are provided in thousands of persons. Other macroeconomic variables are provided in millions of euro.

Source: Institute for Financial Policy.

\section{Discussion of Results}

To evaluate the potential impact of different types of inclusive programmes on the Slovak economy, we assume that the government provides the full support for either the inclusive employers or the social enterprises to achieve the maximal participation in each simulation period. In other words, we set the number of excluded persons that do not participate in the inclusive programmes to zero and then place them on the labour market in a form of inclusive employers or social enterprises. The baseline scenario is set under an absence of inclusive programmes and since we leave other parameters of the model unchanged, we can evaluate a potential impact of the alternative policies on the economic performance. The evaluation of the alternative policies is based on a 10-years simulation horizon. The simulation results without social dumping are presented in the Figure 1 and the simulation results with social dumping are presented in the Figure 2.

We need to mention we abstract from a number of positive effects that result from the employment of socially excluded communities, for example the reduction of generational poverty or the provision of better education. We partially incorporate their higher qualification on the labour market by a higher productivity of the standard employees over the inclusive employees. The inclusive employment should be thus viewed as a form of social investment rather than a form of social transfer.

Furthermore, since these factors could lead to additional gains for the economy, the simulation results should be viewed as the minimal profit from the employment of socially excluded communities. 
Figure 1

A Potential Impact of the Application of Different Types of Inclusive Programmes on the Slovak Economy on a 10-Years Simulation Horizon; The Simulation Results Are Presented for the Scenarios without Social Dumping

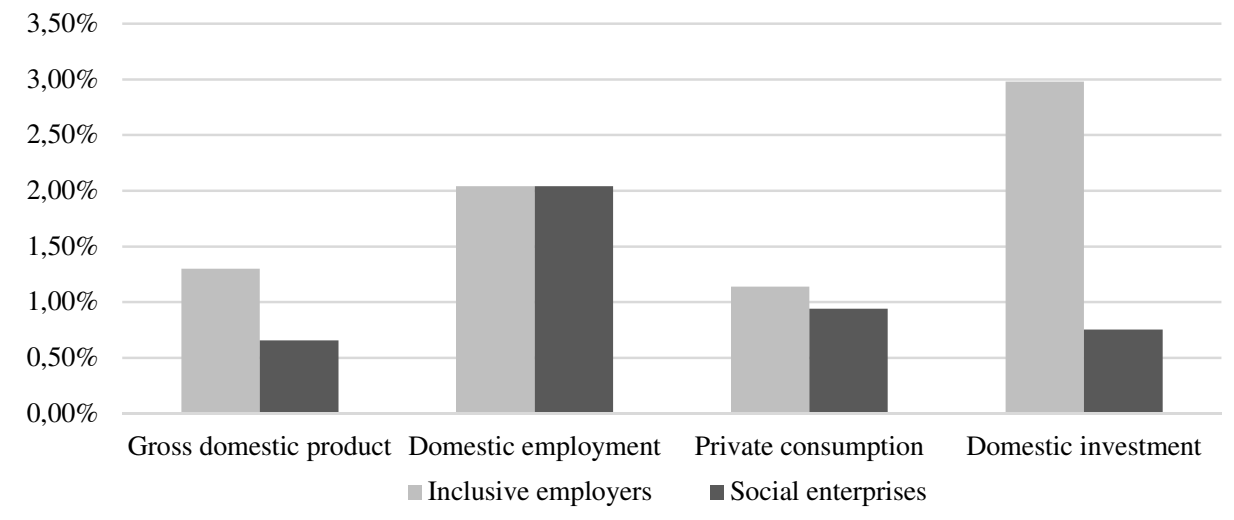

Source: Author's calculations.

Figure 2

A Potential Impact of the Application of Different Types of Inclusive Programmes on the Slovak Economy on a 10-Years Simulation Horizon; The Simulation Results Are Presented for the Scenarios with Social Dumping

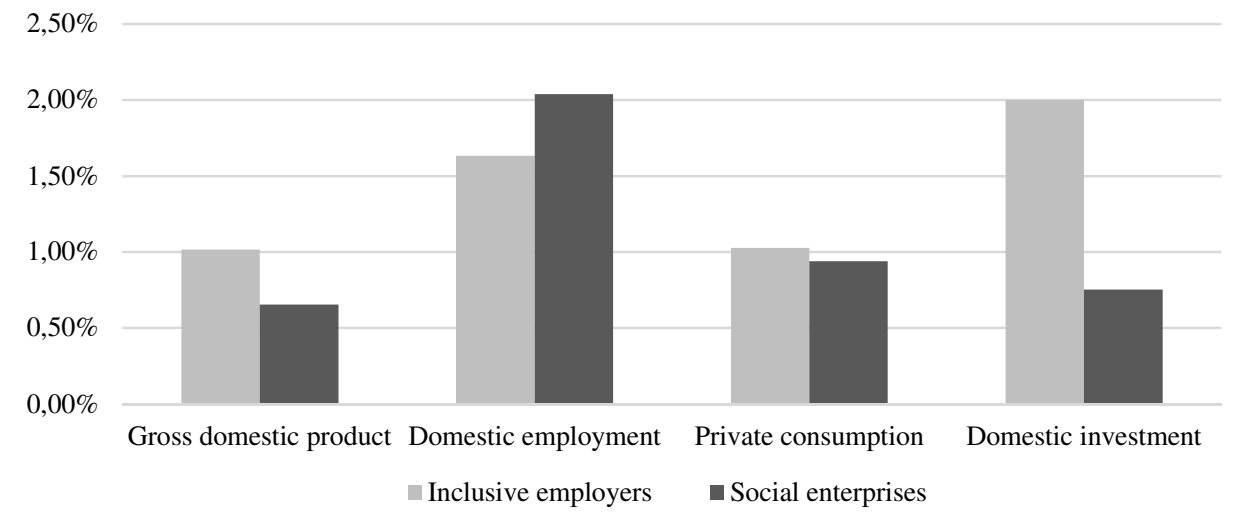

Source: Author's calculations.

\subsection{Simulation Results}

An application of inclusive employers without social dumping could improve the domestic employment by $2.0 \%$ and enhance the gross domestic product by $1.3 \%$ at the end of the simulation horizon (Table 3). The inclusive programmes could further reduce the number of excluded persons by more than $70 \%$. The unemployment rate declines by 0.6 p.p. while the participation rate raises by 0.7 p.p. at the end of the simulation horizon. The private consumption then raises by $1.1 \%$ 
and the domestic investment increases by $3.0 \%$. On the other hand, we observe only a marginal impact of the inclusive programmes on the total trade balance. Finally, even though the application of inclusive employers elevates the public sector deficit by 0.3 p.p. in the first period, the stronger economic performance results in a decline in the public sector debt by 1.4 p.p. at the end of the simulation horizon. The application of inclusive employers without social dumping is thus efficient not only from the macroeconomic perspective but also from the costbenefit point of view.

T a ble 3

A Potential Impact of the Application of Inclusive Employers without Social Dumping on the Slovak Economy on a 10-Years Simulation Horizon

\begin{tabular}{|c|c|c|c|c|c|c|c|c|c|c|}
\hline & $1 Y$ & $2 Y$ & $3 Y$ & $4 Y$ & $5 Y$ & $6 Y$ & $7 Y$ & $8 Y$ & 9Y & $10 \mathrm{Y}$ \\
\hline Gross domestic product & 0.37 & 0.48 & 0.58 & 0.68 & 0.79 & 0.89 & 0.99 & 1.09 & 1.20 & 1.30 \\
\hline Private consumption & 1.05 & 0.99 & 0.96 & 0.96 & 0.96 & 0.98 & 1.01 & 1.05 & 1.09 & 1.14 \\
\hline Domestic investment & -0.96 & -0.34 & 0.21 & 0.70 & 1.15 & 1.56 & 1.94 & 2.30 & 2.65 & 2.98 \\
\hline Trade balance (\% GDP) & 0.00 & -0.01 & -0.01 & -0.01 & -0.01 & -0.01 & -0.01 & -0.01 & -0.01 & -0.01 \\
\hline Domestic employment & 0.34 & 0.63 & 0.89 & 1.12 & 1.33 & 1.51 & 1.67 & 1.81 & 1.93 & 2.04 \\
\hline Excluded population & -11.7 & -22.1 & -31.2 & -39.3 & -46.4 & -52.7 & -58.2 & -63.1 & -67.5 & -71.3 \\
\hline Rate of unemployment & -0.10 & -0.19 & -0.27 & -0.35 & -0.41 & -0.46 & -0.51 & -0.55 & -0.59 & -0.62 \\
\hline Rate of participation & 0.12 & 0.22 & 0.31 & 0.40 & 0.47 & 0.53 & 0.59 & 0.64 & 0.68 & 0.72 \\
\hline Public balance (\% GDP) & -0.32 & -0.20 & -0.10 & -0.01 & 0.07 & 0.13 & 0.19 & 0.25 & 0.29 & 0.34 \\
\hline Public debt (\% GDP) & 0.13 & 0.27 & 0.31 & 0.25 & 0.12 & -0.08 & -0.34 & -0.66 & -1.02 & -1.43 \\
\hline
\end{tabular}

Note: * The simulation results are presented in percentage points over a baseline scenario under an absence of inclusive programmes.

Source: Author's calculations.

On the other hand, the social dumping of inclusive employers limits the positive impact of inclusive programmes on the economic performance. Specifically, the domestic employment improves by $1.6 \%$ and the gross domestic product enhances by $1.0 \%$ at the end of the simulation horizon (Table 4). The social dumping further materializes in a lower mobility of inclusive employees and the number of excluded persons thus declines by less than $60 \%$. Furthermore, the unemployment rate declines by 0.5 p.p. and the participation rate raises by 0.6 p.p. at the end of the simulation horizon.

An application of social enterprises without social dumping has even less pronounced impact on the gross domestic product that improves by less than $0.7 \%$ at the end of the simulation horizon (Table 5).

While the private consumption raises by more than $0.9 \%$, the domestic investment is limited by a worse fiscal position of government and increases by less than $0.8 \%$. On the other hand, the domestic employment improves by $2.0 \%$ and the number of excluded persons declines by more than $70 \%$. The application of social enterprises further elevates the public sector deficit by 0.8 p.p. in the first period what results in an increase in the public sector debt by 2.0 p.p. at the 
end of the simulation horizon. Finally, we abstract from the social dumping of social enterprises.

T a ble 4

A Potential Impact of the Application of Inclusive Employers with Social Dumping on the Slovak Economy on a 10-Years Simulation Horizon

\begin{tabular}{|c|c|c|c|c|c|c|c|c|c|c|}
\hline & $1 Y$ & $2 Y$ & $3 Y$ & $4 Y$ & $5 Y$ & $6 Y$ & $7 Y$ & $8 Y$ & 9Y & $10 \mathrm{Y}$ \\
\hline Gross domestic product & 0.37 & 0.42 & 0.48 & 0.54 & 0.60 & 0.68 & 0.76 & 0.84 & 0.93 & 1.02 \\
\hline Private consumption & 1.05 & 1.01 & 0.98 & 0.96 & 0.95 & 0.95 & 0.96 & 0.98 & 1.00 & 1.03 \\
\hline Domestic investment & -0.96 & -0.64 & -0.31 & 0.03 & 0.36 & 0.69 & 1.03 & 1.36 & 1.68 & 2.00 \\
\hline Trade balance (\% GDP) & 0.00 & -0.01 & -0.01 & -0.01 & -0.01 & -0.01 & -0.01 & -0.01 & -0.01 & -0.01 \\
\hline Domestic employment & 0.19 & 0.37 & 0.55 & 0.73 & 0.90 & 1.06 & 1.22 & 1.37 & 1.50 & 1.63 \\
\hline Excluded population & -6.55 & -13.0 & -19.3 & -25.5 & -31.4 & -37.1 & -42.6 & -47.7 & -52.5 & -57.0 \\
\hline Rate of unemployment & -0.06 & -0.11 & -0.17 & -0.22 & -0.28 & -0.33 & -0.37 & -0.42 & -0.46 & -0.50 \\
\hline Rate of participation & 0.07 & 0.13 & 0.20 & 0.26 & 0.32 & 0.37 & 0.43 & 0.48 & 0.53 & 0.57 \\
\hline Public balance ( $\%$ GDP) & -0.32 & -0.25 & -0.19 & -0.13 & -0.07 & -0.01 & 0.05 & 0.10 & 0.15 & 0.20 \\
\hline Public debt (\% GDP) & 0.13 & 0.35 & 0.51 & 0.60 & 0.62 & 0.58 & 0.48 & 0.32 & 0.10 & -0.16 \\
\hline
\end{tabular}

Note: $*$ The simulation results are presented in percentage points over a baseline scenario under an absence of inclusive programmes.

Source: Author's calculations.

T a ble 5

A Potential Impact of the Application of Social Enterprises without Social Dumping on the Slovak Economy on a 10-Years Simulation Horizon

\begin{tabular}{|l|r|r|r|r|r|r|r|r|r|r|}
\hline & \multicolumn{1}{|c|}{$\mathbf{1 Y}$} & $\mathbf{2 Y}$ & \multicolumn{1}{|c|}{$\mathbf{3 Y}$} & \multicolumn{1}{|c|}{$\mathbf{4 Y}$} & \multicolumn{1}{|c|}{$\mathbf{5 Y}$} & \multicolumn{1}{|c|}{$\mathbf{Y}$} & \multicolumn{1}{|c|}{$\mathbf{Y Y}$} & \multicolumn{1}{c|}{$\mathbf{8 Y}$} & $\mathbf{9 Y}$ & $\mathbf{1 0 Y}$ \\
\hline Gross domestic product & -0.03 & 0.08 & 0.14 & 0.21 & 0.27 & 0.34 & 0.42 & 0.49 & 0.57 & 0.66 \\
Private consumption & 1.44 & 1.27 & 1.15 & 1.06 & 1.00 & 0.96 & 0.94 & 0.93 & 0.93 & 0.94 \\
Domestic investment & -4.59 & -4.01 & -3.23 & -2.52 & -1.86 & -1.26 & -0.70 & -0.19 & 0.30 & 0.75 \\
Trade balance (\% GDP) & 0.16 & 0.24 & 0.20 & 0.16 & 0.12 & 0.08 & 0.05 & 0.02 & -0.01 & -0.04 \\
Domestic employment & 0.34 & 0.63 & 0.89 & 1.12 & 1.33 & 1.51 & 1.67 & 1.81 & 1.93 & 2.04 \\
Excluded population & -11.7 & -22.1 & -31.2 & -39.3 & -46.4 & -52.7 & -58.2 & -63.1 & -67.5 & -71.3 \\
Rate of unemployment & -0.10 & -0.19 & -0.27 & -0.35 & -0.41 & -0.46 & -0.51 & -0.55 & -0.59 & -0.62 \\
Rate of participation & 0.12 & 0.22 & 0.31 & 0.40 & 0.47 & 0.53 & 0.59 & 0.64 & 0.68 & 0.72 \\
Public balance (\% GDP) & -0.79 & -0.58 & -0.44 & -0.33 & -0.24 & -0.15 & -0.08 & -0.02 & 0.04 & 0.09 \\
Public debt (\% GDP) & 0.81 & 1.32 & 1.73 & 2.02 & 2.20 & 2.31 & 2.33 & 2.29 & 2.19 & 2.02 \\
\hline
\end{tabular}

Note: $*$ The simulation results are presented in percentage points over a baseline scenario under an absence of inclusive programmes.

Source: Author's calculations.

\subsection{Sensitivity Analysis}

Next, we present a sensitivity analysis for a functional ratio between the number of inclusive employees and the number of inclusive managers in the social enterprises and its impact on the economic performance. In the baseline scenario, we assume that one inclusive manager is necessary for the employment of four inclusive employees. We then simulate a number of alternative scenarios where we variate this parameter and observe its impact on the economic performance at the end of the simulation horizon. The simulation results of the sensitivity analysis are presented in the Figure 3. 
In general, if one inclusive manager can operate more inclusive employees, we observe a milder crowding out of the labour factor from more effective production sectors what improves the economic performance. However, these differences decline with the scale and are thus much more relevant for a high number of inclusive managers. For example, if we need to apply one inclusive manager per one inclusive employee, we obtain a negative impact of social enterprises on the economic performance, in contrast to a positive impact in the baseline scenario. On the other hand, these differences are relatively small between the applications of one inclusive manager per four and ten inclusive employees. A variation of this parameter has a limited impact on the private consumption but has a significant impact on the domestic investment, in line with a fiscal position of government.

Figure 3

A Sensitivity Analysis for a Functional Ratio between the Number of Inclusive Employees and the Number of Inclusive Managers in the Social Enterprises and Its Impact on the Slovak Economy on a 10-Years Simulation Horizon

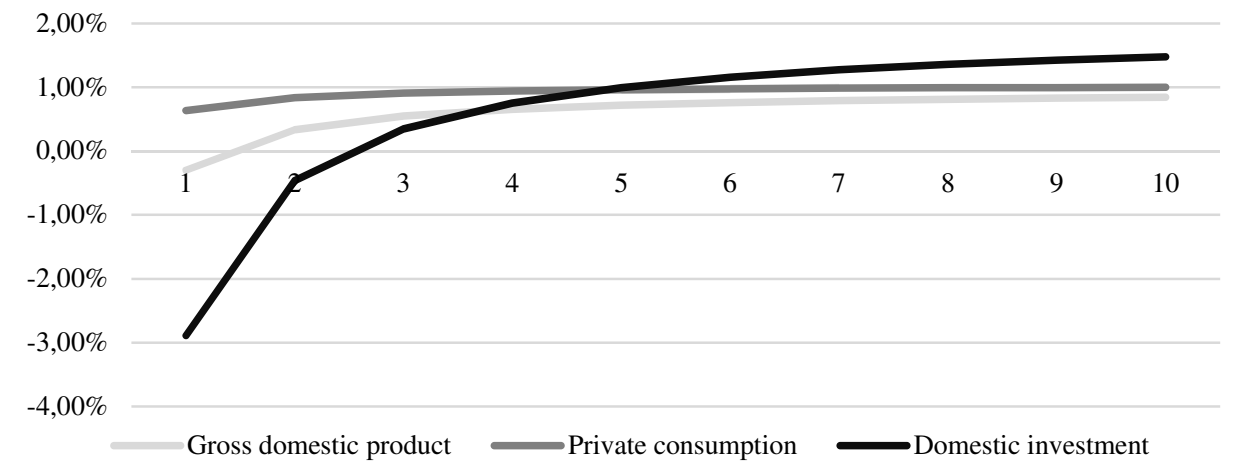

Source: Author's calculations

\section{Concluding Remarks}

In this article, we outlined negative implications of social exclusion on a formation of generational poverty and structural unemployment and proposed a potential solution in a form of inclusive employment. Next, we identified the communities that suffer from social exclusion and structural unemployment and described different types of inclusive programmes that could support their integration to the labour market, with a focus on the inclusive employers and the social enterprises. We then proposed a computable general equilibrium model of a small open economy with two types of producers and two types of households to compare these alternative forms of inclusive employment and evaluate their potential impact on the economic performance. 
Simulation results show that the application of inclusive employers leads to a better improvement of a gross domestic product, in line with a higher productivity of domestic producers and a stronger formation of domestic capital. On the other hand, the social dumping of inclusive employers could limit the mobility of inclusive employees and thus the employment of the excluded communities. Contrary to this, the application of social enterprises provides better labour market prospects for the excluded communities, in line with an absence of social dumping. However, the domestic production could be limited by a worse fiscal position of government and a crowding out of the labour factor from more effective production sectors. The sensitivity analysis implies that a high number of inclusive managers in social enterprises could further limit the economic performance.

\section{References}

ANTMAN, F. - McKENZIE, D. (2007): Poverty Traps and Nonlinear Income Dynamics with Measurement Error and Individual Heterogeneity. The Journal of Development Studies, 43, No. 6, pp. $1057-1083$.

AZARIADIS, C. - STACHURSKI, J. (2004): Poverty Traps. [Working Paper.] Melbourne: University of Melbourne, Department of Economics.

BURFISHER, M. E. (2017): Introduction to Computable General Equilibrium Models. Cambridge: Cambridge University Press. ISBN 978-13-1645-074-1.

CARD, D. - KLUVE, J. - WEBER, A. (2010): Active Labour Market Policy Evaluations: A Meta Analysis. The Economic Journal, 120, No. 548, pp. 452 - 477.

CORONG, E. L. - HERTEL, T. W. - McDOUGALL, R. A. - TSIGAS, M. E. - MENSBRUGGHE, D. (2017): The Standard GTAP Model: Version Seven. Journal of Global Economic Analysis, 2, No. 1 , pp. $1-119$.

DIXON, P. B. - JORGENSON, D. (2012): Handbook of Computable General Equilibrium Modeling. Amsterdam: North Holland Publishing Company. ISBN 978-04-4453-634-1.

DOMONKOS, T. - JÁNOŠOVÁ, M. - OSTRIHOŇ, F. (2013): Analysing Inclusive Growth: Empirical Evidence from the Slovak Republic. Ekonomický časopis/Journal of Economics, 61, No. 9 , pp. $918-933$.

ESCUDERO, V. (2018): Are Active Labour Market Policies Effective in Activating and Integrating Low-Skilled Individuals? An International Comparison. IZA Journal of Labor Policy, 7, No. 1, pp. 1 - 26.

EZAKI, M. (2006): CGE Model and Its Micro and Macro Closures. [Working Paper.] Nagoya: Nagoya University, Graduate School of International Development.

GALLAWAY, M. - McDANIEL, C. - RIVERA, S. (2003): Short-Run and Long-Run IndustryLevel Estimates of U.S. Armington Elasticities. The North American Journal of Economics and Finance, 14, No. 1, pp. $49-68$.

GHARIBNAVAZ, M. R. - VERIKIOS, G. (2018): Estimating LES Parameters with Heterogenous Households for a CGE Model. [Discussion Paper.] West Lafayette: Purdue University, Department of Agricultural Economics.

HIDAS, S. - LAFFÉRSOVÁ, Z. - MACHLICA, G. (2018): Inklúzia Rómov je Celospoločenskou Výzvou. [Roma Inclusion is a Society-Wide Challenge.] [Policy Brief.] Bratislava: Institute for Financial Policy.

HILLBERRY, R. - HUMMELS, D. (2012): Trade Elasticity Parameters for a Computable General Equilibrium Model. Handbook of Computable General Equilibrium Modeling. Cambridge: Cambridge University Press. 
IANCHOVICHINA, E. - LUNDSTROM, S. (2009): Inclusive Growth Analytics: Framework and Application. [Working Paper.] Washington, DC: The World Bank, Economic Policy and Debt Department.

JUNG, H. S. - THORBECKE, E. (2001): The Impact of Public Education Expenditure on Human Capital, Growth and Poverty in Tanzania and Zambia: A General Equilibrium Approach. Journal of Policy Modeling, 25, No. 8, pp. $701-725$.

JUSKO, P. (2015): Zvyšovanie zamestnanosti dlhodobo nezamestnaných v hmotnej núdzi v kontexte stratégie Európa 2020. [Increasing of Employment of Long-Term Unemployed in Material Distress in the Context of Europe 2020 Strategy.] Journal of Modern Science, 26, No. 3, pp. $397-410$.

KABIR, K. - DUDU, H. (2020): Using Computable General Equilibrium Models to Analyze Economic Benefits of Gender-Inclusive Policies. [Working Paper.] Washington, DC: The World Bank, Macroeconomics, Trade and Investment Global Practice.

KAKWANI, N. - PERNIA, E. (2000): What Is Pro-Poor Growth? Asian Development Review, 18 , No. 1 , pp. $1-16$.

KAKWANI, N. - SON, H. (2008): Poverty Equivalent Growth Rate. The Review of Income and Wealth, 54 , No. 4, pp. $643-655$.

KLUVE, J. (2010): The Effectiveness of European Active Labour Market Policy. Labour Economics, 17, No. 6, pp. $904-918$.

LICHNER, I. - MIKLOŠOVIČ, T. (2011): Odhad Elasticity Substitúcie CES Produkčnej Funkcie. [The Estimation of Elasticity of Substitution of CES Production Function.] Forum Statisticum Slovacum, 7, No. 3, pp. $50-55$.

McCULLOCH, N. - BAULCH, B. (2000): Tracking Pro-Poor Growth. [Working Paper.] Brighton: University of Sussex, Institute of Development Studies.

McKENZIE, D. (2017): How Effective Are Active Labour Market Policies in Developing Countries? A Critical Review of Recent Evidence. The World Bank Research Observer, 32, No. 2, pp. $127-154$

MIKLOŠOVIČ, T. (2014): CGE Model a možnosti jeho aplikácie na vybrané zmeny v Slovenskej ekonomike. [CGE Model and Its Possible Application to the Selected Changes in the Slovak Economy.] [Dissertation Thesis.] Bratislava: Faculty of Mathematics, Physics and Informatics, Comenius University in Bratislava.

PÁLENÍK, M. (2015): Štruktúra dlhodobej nezamestnanosti v regiónoch SR. [Long-Term Unemployment Structure in Slovak Regions.] Forum Statisticum Slovacum, 11, No. 2, pp. $79-85$.

PÁLENÍK, V. - PÁLENÍK, M. - ORAVCOVÁ, I. (2013): Inkluzívne zamestnávanie. [Inclusive Employment.] Bratislava: Inštitút Zamestnanosti. ISBN 978-80-9702-044-6.

PÁLENÍK, V. - DOMONKOS, T. - JÁNOŠOVÁ, M. - JUSKO, P. - LICHNER, I. - MIKLOŠOVIČ, T. - OSTRIHOŇ, F. - PÁLENÍK, M. - RADIČOVÁ, I. - RADVANSKÝ, M. ŠTEFÁNIK, M. - ZÁHORSKÁ, J. (2015): Inkluzívny rast v stratégii Európa 2020: Naivita alebo genialita? [Inclusive Growth in the Europe 2020 Strategy: Naivety or Geniality?] Bratislava: Ekonomický ústav Slovenskej akadémie vied. ISBN 978-80-7144-250-9.

VOOREN, M. - HAELERMANS, C. - GROOT, W. - Van den BRINK, H. M. (2018): The Effectiveness of Active Labour Market Policies: A Meta Analysis. Journal of Economic Surveys, 33 , No. 1, pp. $125-149$. 


\section{A p pendix}

The macroeconomic data that were analysed during the current study are available in the repository of the Statistical Office of the Slovak Republic. The data are subject to revision: <http://datacube.statistics.sk/\#!/view/en/VBD_SK_WIN/nu1028rs/v_nu1028rs_00_00_00_en>.

The labour market data that were analysed during the current study are available in the repository of the Statistical Office of the Slovak Republic. The data are subject to revision: <http://datacube.statistics.sk/\#!/view/en/VBD_SK_WIN/nu1024rs/v_nu1024rs_00_00_00_en>.

The capital market data that were analysed during the current study are available in the repository of the Statistical Office of the Slovak Republic. The data are subject to revision:

<http://datacube.statistics.sk/\#!/view/en/VBD_SLOVSTAT/nu2061rs/v_nu2061rs_00_00_00_en>.

The fiscal sector data that were analysed during the current study are available in the repository of the Eurostat of the European Commission. The data are subject to revision:

<https://appsso.eurostat.ec.europa.eu/nui/show.do?dataset=gov_10dd_edpt1\&lang=en>.

The microeconomic data that were analysed during the current study are available from the Institute for Financial Policy but restrictions apply to the availability of these data, which were used under license for the current study, and so are not publicly available. Data are however available upon a reasonable request and with a permission of the Institute for Financial Policy.

Table 6

Calibration of Macroeconomic Elasticities in a Baseline Scenario

\begin{tabular}{|l|cc|cc|}
\hline & Notation & Value & Notation & Value \\
\hline Domestic output elasticity & $\sigma_{n}$ & 2.7520 & $\theta_{n}$ & 0.6366 \\
Domestic export elasticity & $\sigma_{x}$ & 3.9831 & $\theta_{x}$ & 1.2511 \\
Domestic import elasticity & $\sigma_{m}$ & 3.8854 & $\theta_{m}$ & 0.7426 \\
\hline
\end{tabular}

Source: Author's calculations.

T a b l e 7

Calibration of a Sector of Employees in a Baseline Scenario

\begin{tabular}{|l|cc|cc|}
\hline & Notation & Value & Notation & Value \\
\hline Input of inclusive employers & $\kappa_{s}$ & 1.0586 & $\kappa_{i}$ & 0.2745 \\
Input of social enterprises & $\pi_{s}$ & 0.2000 & $\pi_{i}$ & 0.8000 \\
Income from labour market & $\eta_{1}$ & 4.2601 & $\eta_{2}$ & 0.0614 \\
Mobility on labour market & $\lambda_{1}$ & 0.1411 & $\lambda_{2}$ & 0.0088 \\
\hline
\end{tabular}

Source: Author's calculations.

Table 8

\section{Calibration of a Sector of Producers in a Baseline Scenario}

\begin{tabular}{|l|cc|cc|}
\hline & Notation & Value & Notation & Value \\
\hline Total factor effectivity & $\psi_{\mathrm{s}}$ & 2.5579 & $\psi_{i}$ & 6.8425 \\
Relative factor effectivity & $\varphi_{s}$ & 0.5005 & $\varphi_{i}$ & 0.7586 \\
Total output effectivity & $\alpha_{s}$ & 1.9797 & $\alpha_{i}$ & 1.9324 \\
Relative output effectivity & $\beta_{s}$ & 0.4568 & $\beta_{i}$ & 0.4198 \\
\hline
\end{tabular}

Source: Author's calculations. 
Table 9

Calibration of a Sector of Commodities in a Baseline Scenario

\begin{tabular}{|l|cc|cc|}
\hline & Notation & Value & Notation & Value \\
\hline Intermediate input share & $\omega_{s}$ & 0.9874 & $\omega_{i}$ & 0.0126 \\
Private consumption share & $\gamma_{s}$ & 0.9885 & $\gamma_{i}$ & 0.0115 \\
Total export effectivity & $v_{s}$ & 2.0113 & $v_{i}$ & 2.0254 \\
Relative export effectivity & $\xi_{s}$ & 0.5267 & $\xi_{i}$ & 0.5400 \\
Domestic investment share & $\mu_{s}$ & 0.9873 & $\mu_{i}$ & 0.0127 \\
Capital depreciation rate & $\delta_{s}$ & 0.0448 & $\delta_{i}$ & 0.0448 \\
Total import effectivity & $v_{s}$ & 2.0694 & $v_{i}$ & 1.0403 \\
Relative import effectivity & $\zeta_{s}$ & 0.4720 & $\zeta_{i}$ & 0.0000 \\
\hline
\end{tabular}

Source: Author's calculations. 